\title{
Review: Musik dan Denyut Jantung Pada Era Digital
}

\author{
Ifan Kurnia Afandi ${ }^{a^{*}}$, Ridi Ferdiana ${ }^{b}$, Hanung Adi Nugroho ${ }^{c}$ \\ ${ }^{\text {a,b,c }}$ Jurusan Teknik Elektro dan Teknologi Informasi \\ Universitas Gadjah Mada, Yogyakarta
}

Naskah Diterima : 30 Oktober 2014; Diterima Publikasi : 30 Nopember 2014

\begin{abstract}
Heart rate is one of the vital signs of the body health. In addition, the heart is the main pillar of the body in daily activities. Heart rate measurement can be done anywhere with the number of applications on smartphone, the example on Google PlayStore. Today, Digital Lifestyle can not be separated from the smartphone. This can be seen when the daily activities can not be separated from the smartphone. Today's digital lifestyle can not be separated from the music to support day-today activities. Musik digunakan manusia untuk tujuan yang bermacam-macam. Sebagian orang menggunakan musik untuk berelaksasi dan sebagian lainnya menggunakan musik untuk membangkitkan semangat. This paper presents the relationship between heart rate and the music so it can be used for the development of applications on smartphones.
\end{abstract}

Keywords: Heartbeat; Music; Smartphone

\begin{abstract}
Abstrak
Denyut jantung merupakan salah satu dari tanda vital kesehatan tubuh. Selain itu jantung merupakan penopang utama tubuh dalam beraktivitas. Pengukuran denyut jantung dapat dilakukan dimana saja dengan banyaknya aplikasi pada smartphone. Gaya hidup digital sekarang ini tidak dapat dilepaskan dari smartphone. Hal ini dapat dilihat saat aktivitas sehari-hari manusia tidak dapat dilepaskan dari smartphone. Perkembangan gaya hidup digital saat ini tidak dapat dilepaskan dari musik sebagai penunjang aktivitas sehari-hari. Musik digunakan manusia untuk tujuan yang bermacam-macam. Sebagian orang menggunakan musik untuk berelaksasi dan sebagian lainnya menggunakan musik untuk membangkitkan semangat. Paper ini menyajikan tentang hubungan antara denyut jantung dan musik sehingga dapat digunakan untuk pengembangan aplikasi pada smartphone.
\end{abstract}

Keywords: Denyut jantung; Musik; Smartphone.

\section{Pendahuluan}

Musik merupakan bagian yang tidak dapat dipisahkan dalam kehidupan sehari-hari. Dari pelosok dunia dikenal berbagai upacara-upacara tradisional yang menggunakan musik untuk mempengaruhi perilaku psikologis. Orang-orang mendengarkan musik untuk tujuan yang berbeda dalam setiap aktivitasnya, beberapa menggunakan music untuk berelaksasi dan beberapa untuk meningkatkan produktifitasnya.

Pada era modern seperti sekarang ini, manusia cenderung melakukan aktivitas yang tidak dapat dipisahkan dari komputer, laptop, tab, dan smartphone. Kecenderungan manusia untuk selalu berinteraksi melalui komputer, smartphone melalui internet dapat disebut sebagai gaya hidup digital. Gaya hidup digital dapat di gambarkan dalam dua hal yang paling utama yaitu mobilitas dan media. Mobilitas disini dapat didefinisikan sebagai aktivitas yang dapat dikerjakan secara remote dan dapat dilaksanakan dari dan diberbagai tempat. Sedangkan media dapat diartikan sebagai sarana yang dapat menggambarkan suatu hal yang sedang atau telah terjadi. Media dapat berupa gambar, video, audio, ataupun komposisi ketiganya(Boll, 2008).

Gaya hidup digital cenderung membawa manusia untuk menghabiskan sebagian besar waktunya didepan perangkat digital baik untuk bekerja ataupun untuk berhubungan dengan relasinya melalui media sosial (Salehan and Negahban, 2013). Kenyamanan menjadi prioritas utama bagi para pelaku digital lifestyle. Tetapi senyaman apapun ketika suatu aktivitas sudah menjadi rutinitas maka aktivitas tersebut akan mencapai titik jenuh. Rutinitas tersebut akan membawa akibat yang kurang baik, terutama pada kondisi tubuh. Hal tersebut disadari misalnya dengan datangnya rasa kantuk saat rutinitas mencapai titik jenuh. Rasa kantuk ini biasanya timbul seiring dengan melambatnya denyut jantung yang mengakibatkan konsumsi oksigen pada otak yang dibawa oleh darah berkurang. Jika konsumsi oksigen turun maka syaraf otak akan mengirimkan sinyal bahwa tubuh butuh untuk istirahat.

Untuk menghilangkan kantuk seseorang dapat melakukan olahraga ringan. Hal ini bertujuan untuk

*) penulis korespondensi: ifan.afandi@gmail.com 
memenuhi kebutuhan konsumsi oksigen dalam otak. Dengan meningkatnya konsumsi oksigen pada otak maka syaraf akan mengirimkan sinyal pada tubuh bahwa tubuh dalam kondisi optimal. Sehingga dapat disimpulkan bahwa jantung mempunyai peran penting sebagai sarana penilaian psikologis dan penunjang rutinitas manusia (Fleming et al., 2011).

\section{Kerangka Teori}

\subsection{Denyut Jantung}

Kinerja tubuh manusia dapat diukur dari tandatanda vital tubuh. Tanda vital tubuh yaitu denyut jantung, tekanan darah, pernafasan, suhu tubuh. Kinerja jantung merupakan salah satu dari tanda vital dari tubuh (Task Force of The European Society of Cardiology and The North American and Society of Pacing and Electrophysiology, 1996). Fungsi utama dari jantung adalah memompa darah yang membawa zat makanan dan oksigen ke seluruh tubuh. Sehingga saat jantung bekerja optimum maka ketersediaan akan nutrisi dan oksigen tubuh akan terpenuhi. Tetapi apabila denyut jantung mengalami penurunan, maka efek paling terasa yang terjadi adalah timbulnya rasa kantuk.

Denyut jantung merupakan gambaran reaksi psikologis tubuh terhadap lingkungan sekitarnya. Denyut jantung dapat naik atau turun karena terpengaruh stress ataupun pada saat fase istirahat (Acharya et al., 2006). Beberapa penelitian terdahulu salah satunya (Appelhans and Luecken, 2006a) menyatakan bahwa denyut jantung merupakan indek yang dapat memberikan gambaran tentang respon emosional manusia. Respon emosional disini dapat berupa terpengaruhnya denyut jantung pada saat manusia mengalami rasa marah, sedih, tertekan dan sebagainya.

\subsection{Pengukuran Denyut Jantung}

Secara medis pengukuran dilakukan dengan ECG (electrocardiogram). Terdapat beberapa jenis ECG berdasarkan banyak elektroda yang terpasang pada tubuh, sebagai contoh 3-lead ECG, 5-lead ECG, 7lead ECG, dan 12-lead ECG. Tentu saja semakin banyak elektroda yang terpasang pada tubuh akan semakin akurat nilai pembacaannya. Kendala utama yang terjadi jika harus menggunakan ECG adalah tidak tersedianya alat tersebut selain di rumah sakit. Sedangkan pada era digital, manusia cenderung lebih mobile, hal ini mengakibatkan seseorang akan malas untuk meluangkan waktu pergi ke rumah sakit atau klinik. Selain kesulitan tersebut, operator yang menjalankan ECG harus merupakan seorang ahli. dan ketika seseorang ingin mengetahui normal atau tidaknya denyut jantung maka harus dihadapkan dengan prosedur pemeriksaan yang panjang.

Banyak penelitian yang membahas tentang pengukuran denyut jantung menggunakan alat yang lebih portable dan mobile. Secara garis besar semua alat ukut terdiri dari dua bagian yaitu, sensor, pemroses data. Sensor yang dipakai dalam hal ini pengukur denyut jantung antara lain dengan Wireless Sensors Network (WSN), mikro kontroler, photoplethysmography, sensor kamera dan flash. Pemroses data disini misalnya dapat berupa komputer desktop, notebook, ataupun smartphone.

Hii meneliti tentang pengukuran denyut jantung menggunakan protokol zigbee. Penelitian ini menitikberatkan pada pola monitoring keseluruhan tanda vital pada tubuh manusia. Penggunaan WSN memungkinkan alat tersebut sebagai fungsi telemonitoring kesehatan tubuh. Penelitian ini lebih dititikberatkan pada pemasangan berbagai macam sensor pada tubuh, sehingga pola kesehatan dapat terpantau atau dapat dimonitor tanpa melakukan pemeriksaan. Penelitian ini sudah memiliki salah satu aspek utama digital lifestyle yaitu mobilitas. Pemasangan sensor wireless memungkinkan subyek untuk bergerak bebas tanpa terhambat sensor-sensor tersebut (Hii and Chung, 2011a).

Dengan monitoring tanda vital tubuh diharapkan dapat diambil langkah pencegahan secara dini jika terjadi hal-hal yang tidak diinginkan. Penelitian ini merupakan prototype dari konsep smarthealth pada rumah modern. Tetapi prototype ini sangat sulit untuk di implementasikan pada negara berkembang. Banyak faktor yang menghambat implementasinya, misalnya faktor hardware, faktor jaringan, dan tentu saja faktor sumber daya manusia sebagai penggunanya.

Selain dengan WSN banyak penelitian menggunakan antarmuka Bluetooth sebagai basis pengiriman data mentah pada alat komputasinya. Keunggulan dari antarmuka ini adalah sudah tersedianya konektivitas pada perangkat-perangkat dalam kehidupan sehari-hari misalnya smartphone atau notebook. Keunggulan yang diberikan antarmuka Bluetooth adalah konstannya koneksi yang diberikan dalam ruangan. Tetapi sebaliknya koneksi di luar ruangan menjadi kelemahan konektivitas Bluetooth.

Fraille meneliti tentang tanda vital pada tubuh manusia menggunakan zigbee, WSN, rfid, dan sensor suhu. Metode pengukuran melalui tiga tahapan yaitu sensing, actuating, processing. Pada tahapan pertama sensor yang terpasang pada tubuh subyek akan mengumpulkan data mentah berupa suhu tubuh, denyut jantung, tekanan darah. Pada tahapan kedua, data mentah akan melalui proses filtering sehingga data yang akan dikirim pada proses selanjutnya adalah hanya data yang dibutuhkan. Tahapan ini akan dapat meminilmalisasi konsumsi daya yang digunakan. Misalnya subyek dengan gejala flu yang ringan akan terhubung ke database internet untuk mendapatkan solusi. Sedangkan subyek dengan gejala penyakit yang berat akan langsung terhubung dengan staff medis (Fraile et al., 2010).

Penelitian ini sangat baik untuk manajemen kesehatan pada telemonitoring atau smarthealth. Sistem yang komplek akan sangat menyulitkan sistem ini untuk diaplikasikan dalam kehidupan sehari-hari. Selain faktor sumber daya manusia yang belum semua mengerti akan konsep dari smarthealth, faktor biaya yang besar untuk pengadaan dan pemasangan 
sensor merupakan hambatan tersendiri pada implementasi sistem.

Watanabe mengusulkan tentang metode deteksi penyakit jantung. Peralatan yang digunakan meliputi portable ECG dan smartphone. ECG yang digunakan merupakan produk aftermarket tetapi masih menggunakan kabel-kabel elektroda yang terpasang di sekitar dada. Dari ECG data mentah yang didapatkan akan dikirimkan ke smartphone untuk diolah. Pengolahan data mentah pada smartphone dilakukan software yang dapat menyimpulkan apakah terjadi gangguan jantung atau tidak. Ketika olah data menyimpulkan terjadinya gangguan jantung, maka smartphone akan mengirimkan notifikasi atau panggilan darurat. Sistem ini secara keseluruhan sudah baik, tetapi pemasangan ECG yang masih meggunakan kabel elektroda yang terpasang di sekitar dada akan sulit di implementasikan oleh orang yang tidak memahami seluk beluk ECG. Pada dasarnya pengguna akan lebih mementingkan kenyamanan daripada fungsionalitas suatu aplikasi (Watanabe et al., 2012),

Gakare mengusulkan tentang monitoring jantung yang menggunakan portable ECG dan smartphone sebagai unit proses data. Pada sistem tersebut digambarkan secara umum bahwa data mentah yang diperoleh dari ECG dikirimkan pada smartphone yang terhubung dengan internet. Melalui internet aplikasi ini akan terhubung dengan server atau database. Server akan terhubung pada dokter atau staff kesehatan melalui sms atau mms, sehingga setelah itu dokter dapat memberikan nasihat pada pasien. Pada dasarnya penelitian ini membahas tentang modifikasi algoritma Pan Tompkin yang lebih efektif digunakan pada noisy environment. Penelitian ini membahas secara detail tentang algoritma yang digunakan tetapi konsep mobile-health belum dijelaskan secara mendetail (Gakare et al., 2012).

Ming-Zher Poh mengusulkan penelitian pengukuran denyut jantung dengan menggunakan earphone. Prinsipnya reflective photosensor yang terpasang pada earphone akan mendeteksi struktur perubahan cahaya yang melewati daun telinga. Dimana ketika jantung pada fase memompa darah maka dianalogikan cahaya yang lewat pada daun telinga akan cenderung lebih kecil dari pada fase saat jantung pada fase relaksasi. Perubahan pola warna yang diteliti adalah ketika darah kaya akan oksigen darah cenderung berwarna merah cerah. Sedangkan saat oksigen darah sudah terpakai maka darah cenderung berwarna biru keunguan. Penelitian ini mewakili teknologi yang berkembang kearah gaya hidup digital dimana terjadi penyatuan antara mobile device dan aplikasi untuk kesehatan. Tetapi untuk dikembangkan sebagai mobile application masih akan sangat sulit diterapkan, hal yang menjadi kesulitan utamanya adalah menemukan earphone dengan reflective photosensor (Ming-Zher Poh et al., 2012).

Sun-Yuan Ko mengusulkan tentang portable ECG dengan menggunakan modul $E C G$ yang dijual bebas. Modul ini akan terhubung ke smartphone melalui koneksi Bluetooth. Modul ECG akan di letakkan pada suatu sabuk dan dikenakan pada lingkar dada. Pada prinsipnya penelitian ini hanya membuat gambar sinyal yang di peroleh dari modul ECG pada layar android. Untuk pengguna yang tidak mempunyai pengetahuan mendalam tentang karakteristik sinyal jantung akan kesulitan memahami. Faktor kenyamanan selama penggunaan sabuk dengan sensor juga menjadi pertimbangan khusus para pengguna jika sistem ini ingin di implementasikan (Sung-Yuan Ko et al., 2012).

Pola monitoring denyut jantung secara realtime dan dalam tempo waktu yang lama tidak mempunyai fungsi yang esensial diterapkan dalam kehidupan sehari-hari. Kecuali jika pengguna memang sudah terdeteksi mempunyai gangguan jantung. Selain itu monitoring denyut jantung pasa fase relaksasi sudah cukup untuk deteksi dini gangguan pada jantung. Pola monitoring terus menerus justru akan membuang energi untuk pengolahan data, transfer data, dan lain sebagainya.

Tzu-Hao Zen mengajukan penelitian tentang alat pengukur denyut jantung menggunakan mikrokontroler dan smartphone. Data mentah yang di peroleh dari mikrokontroler akan diproses lebih lanjut pada smartphone. Smartphone akan memberikan output berupa gambar grafik denyut jantung, jumlah denyut jantung per menit, dan statusnya. Penelitian ini secara konsep sudah menjelaskan tentang perolehan data dan pemrosesannya, tetapi tidak dijelaskan secara mendetail bagaimana cara mikrokontroler tersebut memperoleh data mentahnya. Status yang pada denyut jantung per menit juga tidak dijelaskan secara detail tentang klasifikasi normal, tinggi atau rendah (Tzu-Hao Yen et al., 2013).

Penelitian ini menjelaskan tentang bagaimana ECG pada smartphone dapat dijadikan deteksi dini pada gangguan jantung berdasarkan denyut jantung yang terekam. Tetapi faktor usia dan kelamin tidak dimasukkan menjadi faktor pertimbangan. Sedangkan denyut jantung akan berbeda karakteristiknya antara laki-laki dan perempuan. Faktor usia juga harus dijadikan dasar untuk mengambil keputusan, karena tingkatan usia mempengaruhi denyut jantung.

Hongqiao Gao dan kawan- engusulkan penelitian tentang multi-lead ECG berbasis smartphone. 7-lead $E C G$ ini menggunakan sensor elektroda yang di pasang di sekitar dada, pengubah sinyal analog ke digital, mikroprosesor STM32 chip yang mengolah data, smartphone berbasis android, dan penggunaan protokol Bluetooth sebagai sarana transfer data dari mikroprosesor STM32 ke smartphone kawan (Hongqiao Gao et al., 2013) .

Penelitian ini diajukan sebagai desain ECG yang mampu memonitor detak jantung, sinyal denyut jantung, dan peringatan dini jika terjadi gangguan pada jantung. Akan tetapi desain ini kurang memperhatikan kenyamanan dari sisi pengguna, adanya alat yang terpasang pada tubuh dengan kabelkabel elektrodanya akan terasa sangat menganggu. Tampilan grafik dari sinyal denyut jantung juga kurang berguna dari sisi pengguna yang belum pernah mendapatkan pengetahuan tentang 
karakteristik sinyal denyut jantung. Menurut Cook (Cook et al., 2006) pada dasarnya fase istirahat dari denyut jantung sudah dapat digunakan untuk deteksi dini kelainan jantung dengan pembanding perokok, kadar kolesterol darah, atau ada tidaknya riwayat hipertensi.

Issac mengajukan penelitian berbasis android smartphone dengan mengkombinasikan dengan 3lead $E C G$. Pada prinsipnya sistem yang diajukan adalah mendeteksi denyut jantung dengan $E C G$ dan jika terdapat anomali yang tidak normal akan mengirimkan peringatan atau notifikasi pada level yang berbeda yaitu kepada pengguna itu sendiri, kepada keluarga (dengan sms notifikasi), dan pada petugas kesehatan (dengan panggilan darurat). Untuk deteksi ECG sistem ini sudah dengan detail menjelaskan baik dari sisi software, hardware, konsep dasar telemonitoring. Yang menjadikan aplikasi ini sulit untuk di implementasikan adalah adanya kabel elektroda yang terpasang di tubuh pengguna. Kenyamanan pengguna merupakan prioritas utama dalam merancang sebuah aplikasi mobile kawan (Issac and Ajaynath, 2012).

Singh menggunakan kamera dan flash pada smartphone untuk mengukur denyut jantung. Kemampuan kamera smartphone yang dapat menangkap gambar dengan kemampuan 20 frame per detik memungkinkan analisis interpulse interval. Interval ini adalah perubahan intensitas cahaya yang tertangkap kamera. Dengan membandingkan perbedaan warna darah kaya oksigen dan yang tidak mengandung oksigen maka dapat dihitung jumlah denyut jantung seseorang. Sebagai pembanding digunakan hardware ardunio dan $L E D$ untuk membandingkan apakah interpulse interval ini mengalami overlap. Penelitian ini masih memerlukan penelitian lebih lanjut untuk mengetahui validitas pengukuran dengan membandingkan dengan ECG (Singh et al., 2012).

Ho telah membandingkan berbagai aplikasi smartphone yang diunduh dari Google Playstore dengan ECG konvensional. Aplikasi yang di unduh menggunakan kamera dan lampu flash untuk menangkap perubahan karakteristik darah pada ujung jari. Penelitian ini menyimpulkan bahwa aplikasi yang di download pada Google Playstore validitasnya dapat dipertanggungjawabkan. Meskipun masih diperlukan studi lebih lanjut untuk mengetahui apakah valid digunakan pada tingkatan umur yang bervariasi (Ho et al., 2013).

Gregoski membandingkan beberapa aplikasi yang menggunakan smartphone dengan berbagai alat pengambil data mentah denyut jatung. Yang pertama menggunakan alat ECG yang biasa berada pada klinik kesehatan. Yang kedua menggunakan bio sensor yang biasa dijual bebas sebagai alat kesehatan. Yang ketiga adalah penggunaan kamera pada smartphone dengan resolusi 5 mega pixel yang dilengkapi dengan lampu flash. Pada alat pertama dan kedua tentu saja hasil ukur sudah diuji sebelum di pasarkan, tatapi pada alat yang ketiga sebagai alat berbiaya murah dan mudah digunakan harus dibandingkan dengan alat yang sudah teruji. Limitasi uji yang hanya mengukur jumlah denyut jantung disini memberi nilai tambah untuk diterapkan dalam aplikasi mobile (Gregoski et al., 2012).

Konsep yang digunakan dalam mengukur denyut jantung menggunakan kamera adalah dengan membandingkan perubahan warna darah yang terrekam antara darah yang kaya akan oksigen dan darah yang tidak mengandung oksigen. Prinsipnya darah yang kaya akan oksigen berwarna merah terang, dan yang tidak mengandung oksigen akan tampak berwarna ungu atau kebiruan pada lensa kamera. Prinsip tersebut juga digunakan dalam oksimeter yang dijual di pasaran. Kesimpulan yang diperoleh dari perbandingan ini adalah bahwa kamera smartphone dapat digunakan untuk mengukur denyut yang valid dari tingkatan fase istirahat sampai dengan fase kerja ringan atau fase optimum denyut jantung.

Banyaknya penelitian yang mengukur denyut jantung menggunakan smartphone. Tetapi banyak pula penelitian yang sangat sulit untuk di implementasikan dalam kehidupan sehari-hari. Padahal smartphone merupakan cerminan dari gaya hidup digital dimana pengguna membutuhkan kenyamanan, mobilitas, media sebagai teman dalam melakukan aktivitasnya. Perancangan aplikasi yang nyaman tanpa mengesampingkan faktor kebergunaan menjadi kunci utama suatu aplikasi akan banyak diadopsi.

\subsection{Musik dan Denyut Jantung}

Denyut jantung dan emosi sangat erat kaitannya (Appelhans and Luecken, 2006b). Contohnya ketika manusia sedang pada fase temperamen yang tinggi maka jantung cenderung berdenyut lebih kencang. Demikian juga sebaliknya, ketika manusia pada fase istirahat jantung cenderung akan berdenyut pelan. Selain berhubungan dengan denyut jantung emosi juga dapat dihubungkan dengan musik. Musik dengan tempo yang lambat cenderung menenteramkan dan memperlambat denyut jantung. Musik dengan tempo yang cepat cenderung membawa perasaan yang meledak-ledak dan meningkatkan denyut jantung.

Musik merupakan instrumen alam (Guerreiro, 2012) yang dapat mempengaruhi denyut jantung seseorang. Penelitian yang membahas kaitan musik dengan denyut jantung telah banyak dilakukan. Gianfranco Cervellin meneliti bahwa musik dapat mempengaruhi fungsi neurologi tubuh dan memodulasi denyut jantung. Carvellin juga menyimpulkan bahwa musik mempunyai efek untuk mereduksi tingkat stress seseorang. Minimnya penelitian tentang efek musik pada kesehatan manusia mengakibatkan adopsi musik untuk aplikasi kesehatan sangat jarang (Cervellin and Lippi, 2011).

Pengaruh musik terhadap denyut jantung telah diteliti oleh Santoso (2002). Disimpulkan bahwa musik dengan tempo yang lambat akan mereduksi denyut jantung. Penelitian dilakukan pada saat obyek yang sedang beraktivitas. Penelitian ini berfokus pada relaksasi, sehingga musik dapat digunakan pada terapi pengobatan dengan keluhan kecemasan. 
Penelitian ini belum mencakup apakah tempo musik yang cepat akan mempercepat denyut jantung atau tidak.

Zeydi menyimpulkan bahwa musik mempunyai efek yang positif terhadap denyut jantung, konsumsi oksigen setelah operasi. Penelitian ini di titik beratkan untuk menjaga kestabilan denyut jantung dan relaksasi setelah operasi. Penelitian ini belum menjelaskan apakah tempo musik berpengaruh pada denyut jantung atau tidak karena lebih berkonsentrasi untuk relaksasi jantung (Zeydi et al., 2011).

Dousty dan Daneshvar meneliti tentang beberapa jenis musik dan pengaruhnya terhadap daya listrik yang dihasilkan oleh jantung. Dimana diketahui ketika jantung berdenyut akan menghasilkan energi listrik yang berbeda-beda, baik pada fase normal, relaksasi ataupun fase maksimal. Penelitian ini menyimpulkan bahwa musik berpengaruh terhadap listrik yang dihasilkan ketika jantung sedang bekerja (Dousty dan Daneshvar, 2010).

Penelitian-penelitian terdahulu masih cenderung sulit untuk diterapkan dalam kehidupan sehari-hari untuk menunjang mobilitas pengguna. Banyak penelitian yang di fokuskan pada relaksasi denyut jantung (Loomba et al., 2012) (Loewy et al., 2013) (Kurita et al., 2006) (Peng Zhou et al., 2010). Tetapi sebaliknya penelitian yang memfokuskan bagaimana musik untuk mengoptimisasi denyut jantung masih sangat jarang dilakukan.

Thomas dan Ho meneliti tentang keterkaitan antara perubahan denyut jantung dengan tempo musik dengan membangun aplikasi iHeartLift. Penelitian ini menggunakan alat ECG yang terdapat pada fasilitas klinis yang telah teruji keakuratannya. Subyek yang diteliti diacak dengan 2 eksperimen yang berbeda (Ho dan Chen, 2011). Eksperimen pertama monitor perubahan denyut jantung tanpa menggunakan aplikasi iHeartLift. Dan eksperimen kedua menggunakan aplikasi dan dimonitor sejauh mana kenaikan denyut jantungnya. Sampel musik yang digunakan acak tidak di ditentukan dalam satu aliran musik tertentu. Didasarkan dari penelitian sebelumnya (McCraty et al., 2001) yang menyatakan bahwa aliran musik mempengaruhi denyut jantung dengan karakteristik yang berbeda.

Aplikasi iHeartLift memberikan gambaran baru bahwa musik dapat meningkatkan variable denyut jantung. Kesimpulan tersebut dapat menjadi dasar untuk pengembangan aplikasi mobile yang bertujuan untuk meningkatkan denyut jantung. Dari tabel 1 dibawah ini dapat dilihat bahwa secara teknik penelitian tentang pengukuran denyut jantung telah banyak dilakukan.

Tabel 1. Tabel review

\begin{tabular}{|c|c|c|c|}
\hline Penelitian & Teknik & + & - \\
\hline $\begin{array}{l}\text { (Hii and Chung, 2011b) } \\
\text { (Fraile et al., 2010) }\end{array}$ & $\begin{array}{l}\text { Sensors, WSN, zigbee, } \\
\text { internet }\end{array}$ & $\begin{array}{l}\text { Pengukuran secara } \\
\text { realtime }\end{array}$ & Sulit diterapkan \\
\hline $\begin{array}{l}\text { (Watanabe et al., 2012) } \\
\text { (Gakare et al., 2012) (Sung- } \\
\text { Yuan Ko et al., 2012) (Tzu- } \\
\text { Hao Yen et al., 2013) } \\
\text { (Hongqiao Gao et al., } \\
\text { 2013)(Issac and Ajaynath, } \\
\text { 2012) }\end{array}$ & $\begin{array}{l}\text { Smartphone, Sensors } \\
\text { ECG, mikrokontroler, } \\
\text { kabel katoda, } \\
\text { telemonitoring }\end{array}$ & Akurat, mobile, internet & Sulit diterapkan \\
\hline $\begin{array}{l}\text { (Ming-Zher Poh et al., 2012) } \\
\text { (Singh et al., 2012) }\end{array}$ & Interpulse interval & Smartphone, Mobile, & Perlu studi lanjutan \\
\hline $\begin{array}{l}\text { (Ho et al., 2013) (Gregoski et } \\
\text { al., 2012) }\end{array}$ & $\begin{array}{l}E C G, E C G \\
\text { smartphone, interpulse } \\
\text { interval }\end{array}$ & $\begin{array}{l}\text { Interpulse interval, } \\
\text { pengukuran yang akurat }\end{array}$ & Perlu studi lanjutan \\
\hline $\begin{array}{l}\text { (Cervellin and Lippi, 2011) } \\
\text { (Dedik S. Santoso, 2002) } \\
\text { (Loomba et al., 2012) (Loewy } \\
\text { et al., 2013) (Kurita et al., } \\
\text { 2006) (Peng Zhou et al., 2010) }\end{array}$ & Relaksasi & $\begin{array}{l}\text { Hubungan musik dan } \\
\text { denyut jantung dan } \\
\text { pengukuran yang akurat }\end{array}$ & $\begin{array}{l}\text { Berupa aplikasi } \\
\text { desktop }\end{array}$ \\
\hline $\begin{array}{l}\text { (Zeydi et al., 2011) (Dousty } \\
\text { and Daneshvar, 2010) }\end{array}$ & $\begin{array}{l}\text { Stabilitas denyut } \\
\text { jantung }\end{array}$ & $\begin{array}{l}\text { Hubungan musik dan } \\
\text { denyut jantung, konsumsi } \\
\mathrm{SPO}_{2} \text {, Pengukuran yang } \\
\text { akurat }\end{array}$ & $\begin{array}{l}\text { Berupa aplikasi } \\
\text { desktop }\end{array}$ \\
\hline (Ho and Xiang Chen, 2011) & $\begin{array}{l}\text { Peningkatan denyut } \\
\text { jantung }\end{array}$ & Alat yang digunakan teruji & $\begin{array}{l}\text { Berupa aplikasi } \\
\text { desktop }\end{array}$ \\
\hline
\end{tabular}


Mayoritas penelitian yang dilakukan menggunakan sensor WSN, mobile ECG, dihubungkan dengan kabel katoda atau Bluetooth. Hal tersebut tidak dapat diterapkan pada aplikasi mobile.

Beberapa penelitian diatas juga mengamati tentang hubungan musik dan denyut jantung. Banyak fokus penelitian pada relaksasi jantung, meskipun beberapa penelitian menyertakan variable yang lain. Penelitian tentang peningkatan variabel denyut jantung dapat dijadikan acuan untuk mengembangkan aplikasi mobile.

\section{Kesimpulan}

Berdasarkan review diatas dapat disimpulkan bahwa musik berpengaruh pada denyut jantung, sehingga musik dapat digunakan sebagai alternatif untuk menaikan denyut jantung untuk menunjang aktivitas seseorang pada era digital. Hasil akhir yang diharapkan adalah aplikasi mobile yang dapat digunakan untuk meningkatkan denyut jantung.

\section{Daftar Pustaka}

Acharya, U.R., Joseph, K.P., Kannathal, N., Lim, C.M., Suri, J.S., 2006. Heart rate variability: A review. Med. Biol. Eng. Comput. 44, 1031-1051. doi:10.1007/s11517-006-0119-0

Appelhans, B.M., Luecken, L.J., 2006a. Heart rate variability as an index of regulated emotional responding. Rev. Gen. Psychol. 10, 229-240. doi:10.1037/1089-2680.10.3.229

Appelhans, B.M., Luecken, L.J., 2006b. Heart rate variability as an index of regulated emotional responding. Rev. Gen. Psychol. 10, 229-240. doi:10.1037/1089-2680.10.3.229

Boll, S., 2008. Inside Digital, Life, Design 2008. Multimed. IEEE 15, 8-12. doi:10.1109/MMUL.2008.33

Cervellin, G., Lippi, G., 2011. From music-beat to heart-beat: a journey in the complex interactions between music, brain and heart. Eur. J. Intern. Med. 22, 371-374.

Dedik S. Santoso, 2002. PENGARUH MUSIK TERHADAP PERFORMANCE FISIK. JURNAL TEKNIK INDUSTRI VOL. 4, 1 - 7 .

Dousty, M., Daneshvar, S., 2010. The effect of different kind of music and silences on electrical heart working. Isfahan. doi:10.1109/ICBME.2010.5704936

Fleming, S., Thompson, M., Stevens, R., Heneghan, C., Plüddemann, A., Maconochie, I., Tarassenko, L., Mant, D., 2011. Normal ranges of heart rate and respiratory rate in children from birth to 18 years of age: a systematic review of observational studies. The Lancet 377, 1011-1018.

Fraile, J.A., Bajo, J., Corchado, J.M., Abraham, A., 2010. Applying Wearable Solutions in Dependent
Environments. Inf. Technol. Biomed. IEEE Trans. On 14, 1459-1467. doi:10.1109/TITB.2010.2053849

Gakare, P.K., Patel, A.M., Vaghela, J.R., Awale, R.N., 2012. Real time feature extraction of ECG signal on android platform. Presented at the Communication, Information \& Computing Technology (ICCICT), 2012 International Conference on, pp. 1-5 doi:10.1109/ICCICT.2012.6398230

Gregoski, M.J., Mueller, M., Vertegel, A., Shaporev, A., Jackson, B.B., Frenzel, R.M., Sprehn, S.M., Treiber, F.A., 2012. Development and validation of a smartphone heart rate acquisition application for health promotion and wellness telehealth applications. Int. J. Telemed. Appl. 2012, 1.

Guerreiro, V., 2012. Thinking clearly about music. Teorema 31, 25-47.

Hii, P., Chung, W., 2011a. A comprehensive ubiquitous healthcare solution on an Android ${ }^{\mathrm{TM}}$ mobile device. Sensors 11, 6799-6815.

Hii, P., Chung, W., 2011b. A comprehensive ubiquitous healthcare solution on an Android $^{\mathrm{TM}}$ mobile device. Sensors 11, 6799-6815.

Ho, C.-L.. b, Fu, Y.-C.. c, Lin, M.-C.. c, Chan, S.-C.., Hwang, B.., Jan, S.-L.. c, 2013. Smartphone Applications (Apps) for Heart Rate Measurement in Children: Comparison with Electrocardiography Monitor. Pediatr. Cardiol. 16. doi:10.1007/s00246-013-0844-8

Gao, H., Duan, X., Guo, X., Huang, A., Jiao, B., 2013. Design and tests of a smartphones-based multi-lead ECG monitoring system. Presented at the Engineering in Medicine and Biology Society (EMBC), 2013 35th Annual International Conference of the IEEE, pp. 2267-2270. doi:10.1109/EMBC.2013.6609989

Ho, T.C.T., Chen, X., 2011. iHeartLift: A closed loop system with bio-feedback that uses music tempo variability to improve heart rate variability. Presented at the Engineering in Medicine and Biology Society,EMBC, 2011 Annual International Conference of the IEEE, pp. 11811184. doi:10.1109/IEMBS.2011.6090277

Issac, R., Ajaynath, M.S., 2012. CUEDETA:A real time heart monitoring system using android smartphone. Presented at the India Conference (INDICON), 2012 Annual IEEE, pp. 047-052. doi:10.1109/INDCON.2012.6420587

Ko, S.Y., Wang, K.M., Lian, W.C., Kao, C.H., 2012. A portable ECG recorder. Presented at the Consumer Electronics, Communications and Networks (CECNet), 2012 2nd International Conference on, pp. 3063-3067. doi:10.1109/CECNet.2012.6201460

Kurita, A., Takase, B., Okada, K., Horiguchi, Y., Abe, S., Kusama, Y., Atarashi, H., 2006. Effect of music therapy on heart rate variability in elderly 
patients with cerebral vascular disease and dementia. J Arrhythmia 22, 161-6.

Loewy, J.., Stewart, K.. e, Dassler, A.-M.., Telsey, A.., Homel, P.. d, 2013. The effects of music therapy on vital signs, feeding, and sleep in premature infants. Pediatrics 131, 902-918. doi:10.1542/peds.2012-1367

Loomba, R.S., Shah, P.H., Chandrasekar, S., Arora, R., Molnar, J., 2012. Effects of music on systolic blood pressure, diastolic blood pressure, and heart rate: A meta-analysis. Indian Heart J. 64, 309313. doi:10.1016/S0019-4832(12)60094-7

Ming-Zher Poh, Kim, K., Goessling, A., Swenson, N., Picard, R., 2012. Cardiovascular Monitoring Using Earphones and a Mobile Device. Pervasive Comput. IEEE 11, 18-26. doi:10.1109/MPRV.2010.91

Zhou, P., Sui, F., Zhang, A., Wang, F., Li, G., 2010. Music therapy on heart rate variability. Presented at the Biomedical Engineering and Informatics (BMEI), 2010 3rd International Conference on, pp. 965-968. doi:10.1109/BMEI.2010.5639814

McCraty, R., Atkinson, M., Tomasino, D., 2001. Science of the heart: exploring the role of the heart in human performance. Inst. Hear. Res. Staff 1.

Salehan, M., Negahban, A., 2013. Social networking on smartphones: When mobile phones become addictive. Comput. Hum. Behav. 29, 2632-2639. doi:10.1016/j.chb.2013.07.003

S, C., Togni, M., Schaub, M., 2006. High heart rate: a cardiovascular risk factor? Eur. Heart J., 20 27, 2387-2393.
Singh, K., Crilly, P., Muthukkumarasamy, V., 2012. Sensing and analyzing physiological data with a smart phone to secure an e-health system. Presented at the Communications and Information Technologies (ISCIT), 2012 International Symposium on, pp. 302-307. doi:10.1109/ISCIT.2012.6380911

Task Force of The European Society of Cardiology and The North American, Society of Pacing and Electrophysiology, 1996. Heart rate variability. Eur. Heart J. 17, 354-381.

Watanabe, H., Kawarasaki, M., Sato, A., Yoshida, K., 2012. Development of wearable heart disease monitoring and alerting system associated with smartphone. Presented at the e-Health Networking, Applications and Services (Healthcom), 2012 IEEE 14th International Conference on, pp. 292-297. doi:10.1109/HealthCom.2012.6379423

Yen, T.H., Chang, C.Y., Yu, S.N., 2013. A portable real-time ECG recognition system based on smartphone. Presented at the Engineering in Medicine and Biology Society (EMBC), 2013 35 th Annual International Conference of the IEEE, pp. 7262-7265. doi:10.1109/EMBC.2013.6611234

Zeydi, A.E.., Jafari, H.., Khani, S.., Esmaeili, R.., Baradari, A.G.., 2011. The effect of music on the vital signs and $\mathrm{SpO} 2$; of patients after open heart surgery: A randomized clinical trial. J. Mazandaran Univ. Med. Sci. 20, 72-82. 